\title{
Performance Analysis of Positive Output Super-Lift Re-Lift Luo Converter With PI and Neuro Controllers
}

\author{
A. Joseph Basanth ${ }^{1}$, S.P.Natarajan ${ }^{2}$, T.S.Sivakumaran ${ }^{3}$ \\ ${ }^{1}$ (Research Scholar, Department of Instrumentation Engineering, Annamalai University India.) \\ ${ }^{2}$ (Professor and Head, Department of Instrumentation Engineering, Annamalai University, India) \\ ${ }^{3}$ (Dean(PG Studies), Arunai College of Engineering, Anna University, India)
}

\begin{abstract}
DC-DC converters are widely used in computer peripheral equipments and industrial applications. Luo converter is a recently developed DC-DC converter. Positive output Luo converter performs the conversion from positive source voltage of one level to positive load voltage of another required level This paper presents simulation of PI and neuro controllers for a positive output super-lift re-lift DC-DC converter. Super lift converters make the output voltage increasing in geometric progression. They are different from any other existing DC-DC converters and possess many advantages including very high output voltage with small ripples. Therefore these converters will be widely used in industrial applications especially for very high voltage projects. Control algorithm is developed in this work to ensure tracking of the reference voltage and rejection of system disturbances by successive measurements of the converter output voltage at certain time instants within a conduction period. The main objective is simulation of PI and neuro controllers using MATLAB (version 7.1) software and evaluate the controller's performances. The simulation results show that neuro controller provides quicker settling of output whereas PI controller creates less over shoot.
\end{abstract}

Keywords - Luo converter, MOSFET, Neuro,PI

\section{Introduction}

DC-DC converters are used to convert power at one voltage level to power at another voltage level. These converters are widely used in computer peripheral equipments and industrial applications. The output voltage of Pulse Width Modulation (PWM) based DC-DC converters can be varied by varying the duty cycle of the switching device of these converters. Luo converters are a recently developed subset of DC-DC converters. Positive output super lift converters provide positive output voltage of any required level from positive input source voltage. In DC - DC converter due to the effect of parasitic elements, the output voltage and power transfer efficiency is restricted. The voltage-lift technique is a popular method that is widely applied in electronic circuit design. It can open a good way of improving DC-DC converters characteristics and has been successfully applied for DC-DC converters [1-9]. Super lift converters [1] are a series of new DC-DC converters which were developed from prototypes using the voltage- lift technique. This converter implements the output voltage increasing in stage by stage along the geometric progression. It effectively enhances the voltage transfer gain in power series. They are different from any other existing DC-DC converters and possess many advantages including a high output voltage with small ripples. Since power electronics systems like super lift Luo converter (re-lift circuit) have non-linear characteristics and PI and neuro controllers are found to provide satisfactory control for such converters [8,9], such controllers are used in this work to vary the duty cycle for regulating the output voltage of chosen Luo converter. The tests for load regulation and line regulation are carried out to evaluate the controller's performances. The results are presented.

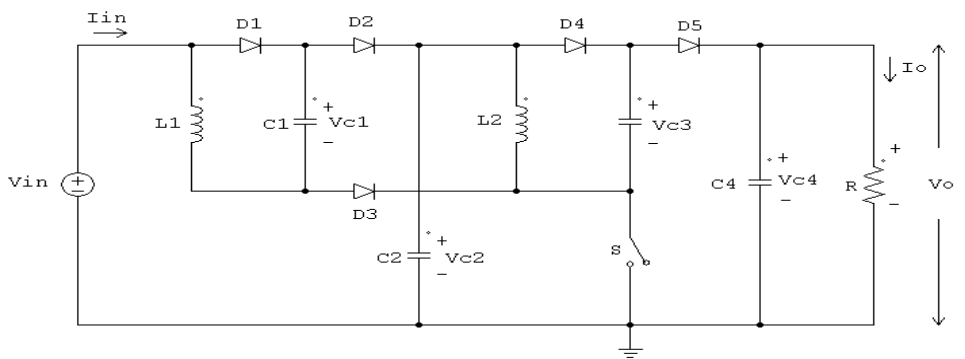

Fig.1. Re-Lift circuit

Fig. 1 shows the re-lift circuit of positive output super-lift Luo converter. This re-lift circuit can perform step-up DC-DC conversion. The re-lift circuit is derived from elementary circuit. Switch $S$ in these circuits is a P-channel power MOSFET device (PMOS). It is driven by a Pulse Width Modulated (PWM) switching signal with operating frequency $\mathrm{f}$ and conduction duty cycle $\mathrm{k}$. In this condition, the switch repeating period is $\mathrm{T}=1 / \mathrm{f}$ 
so that the switch-on period is kT and the switch-off period is (1-k) T. For all circuits, the loads are usually resistive. Fig. 2 and Fig. 3 show the re-lift circuit of positive output super-lift during switch on and off.

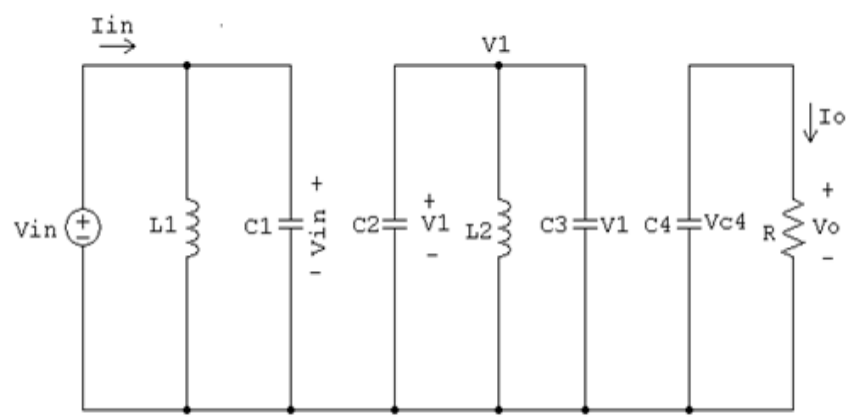

Fig.2.Equivelent circuit during switch on

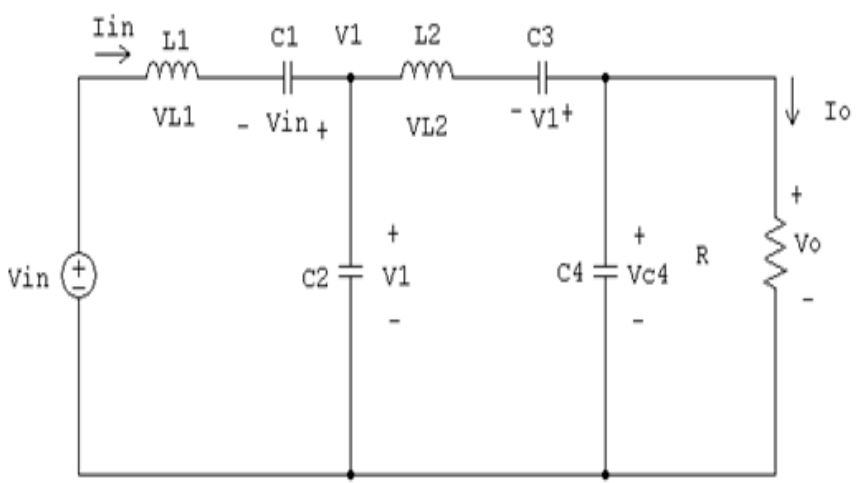

Fig.3. Equivelent circuit during switch off

\section{Open-Loop Converter Dynamics}

The open loop converter system (Fig. 4) comprises the power stage discussed in the previous section. The input of the power stage are supply Vs and duty ratio D and output is Vo.Generally Vs is maintaied at a constant value.

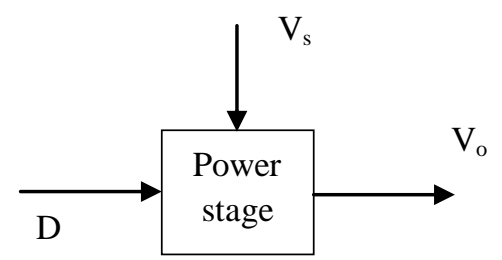

Fig.4. Block diagram of open loop converter

\section{Design of Conventional Controller}

Many industrial processes are non-linear and are thus complicated to be described mathematically. However, it is known that a good many non-linear processes can satisfactorily be controlled using PID controllers provided the controller parameters are tuned well. Practical experience shows that this type of control has a lot of sense since it is simple and based on three basic behavior types or modes: proportional $(\mathrm{P})$, integrative (I) and derivative (D). Instead of using a small number of complex controllers, a larger number of simple PID controllers are used to control complex processes in an industrial assembly in order to automate the certain more complex process. Controllers of different types such as P, PI and PD are today basic building blocks in control of various processes. In spite of simplicity, they can be used to solve even a very complex control problem, especially when combined with different functional blocks, filters (compensators or correction blocks), selectors etc. A continuous development of new control algorithms ensure that the PID controller has 
not become obsolete and that this basic control algorithm will have its part to play in process control in foreseeable future. It can be expected that it will be a backbone of many complex control systems. While proportional and integrative modes are also used as single control modes, a derivative mode is rarely used in control systems. PI controller forms the control signal $\mathrm{U}(\mathrm{t})$ from error e $(\mathrm{t})$ in the following way:

$$
U(t)=K_{p}\left[e(t)+\frac{1}{T} \int_{0}^{t} e(\tau) d \tau\right]
$$

Where $K_{p}$ and $T_{i}$ are PI controller settings. The tuning of this controller is done using the reaction curve method. PI controller settings $\mathrm{K}_{\mathrm{p}}$ and $\mathrm{T}_{\mathrm{i}}$ are designed using Ziegler-Nichols tuning technique based on the converter's open loop step responses with above loads. Controller tuning involves the selection of the best values of $\mathrm{K}_{\mathrm{p}}$ and $T_{i}$. This is often a subjective procedure and is certainly process dependent. $K_{p}=0.205, T_{i}=0.000025$ in this work.

\section{Design of Neuro Controller}

Neural networks, with the abilities of real-time learning, parallel computation and self organizing, make pattern classification more suitable to handle complex classification problems through their learning and generalization abilities. An Artificial Neural Network (ANN) based controller has been developed in this work. The feed-forward ANN has been trained on line using standard Back Propagation (BP) algorithm as opposed to most of the applications of the feed-forward neural nets where training is performed off line using pre-stored data. In general, each online training epoch consists of propagating the ANN input vector to compute its output, comparing this output with some reference to compute the training error and finally modifying the ANN weights in such a way as to reduce the magnitude of this error to obtain the optimum value. Similar training is done with all the patterns so that matching occurs for all the functions. Back propagation is the most popular training method for a multi-layer feed forward network. The ANN with back propagation algorithm is trained with fifty thousand data for line and load disturbances. The topology is trained with one input layer, five hidden layers and one output layer with standard purelin and tan sigmoid activation functions. The input to the neural controller is the output voltage error (difference between actual output voltage under supply/load disturbance and the required output voltage (set point or reference output)) and the controller output is the updated duty ratio. Table 1 shows the specification of circuit parameters.

Table:1:Specification of circuit parameters

\begin{tabular}{|l|l|}
\hline Parameters & Specification \\
\hline Input voltage (nominal) & $12 \mathrm{~V}$ \\
\hline Output voltage & $24 \mathrm{~V}$ \\
\hline Load resistance(nominal) & $100 \Omega$ \\
\hline Switching frequency & $50 \mathrm{kHz}$ \\
\hline Filter inductance & $100 \mu \mathrm{H}$ \\
\hline Filter capacitance & $5 \mu \mathrm{F}$ \\
\hline
\end{tabular}

\section{Simulation Results}

Figs. 5-6 show the closed loop response of start-up of output voltage and current of the positive output super-lift re-lift Luo converter with set point $24 \mathrm{~V}$ and nominal load $100 \Omega$ with PI controller. Figs. 7-8 display the simulated output voltage and current of the positive output super-lift re-lift Luo converter with sudden line disturbances $(12 \mathrm{~V}-15 \mathrm{~V}-12 \mathrm{~V})$ at $\mathrm{t}=0.01 \mathrm{sec}$ and $0.03 \mathrm{sec}$ respectively with PI controller and nominal load $100 \Omega$. Figs. 9-10 illustrate the simulated output voltage and current of the same converter with sudden load disturbances $(100 \Omega-90 \Omega-100 \Omega)$ with PI controller at $\mathrm{t}=0.05 \mathrm{sec}$ and $0.07 \mathrm{sec}$ respectively. Figs. 11-12 show the closed loop response of start-up of output voltage and current of the positive output super-lift re-lift Luo converter with set point $24 \mathrm{~V}$ and nominal load $100 \Omega$ with neuro controller. Figs. 13-14 display the simulated output voltage and current of the positive output super-lift re-lift Luo converter with sudden line disturbances $(12 \mathrm{~V}-15 \mathrm{~V}-12 \mathrm{~V})$ at $\mathrm{t}=0.01 \mathrm{sec}$ and $0.03 \mathrm{sec}$ respectively with neuro controller and nominal load $100 \Omega$. Figs. 15 16 illustrate the simulated output voltage and current of the positive output super-lift re-lift Luo converter with sudden load disturbances $(100 \Omega-90 \Omega-100 \Omega)$ with neuro controller at $\mathrm{t}=0.05 \mathrm{sec}$ and $0.07 \mathrm{sec}$ respectively. Tables 2 and 3 show the performance evaluation of positive output super-lift re-lift Luo converter with PI and neuro controllers. 


\subsection{PI controller}

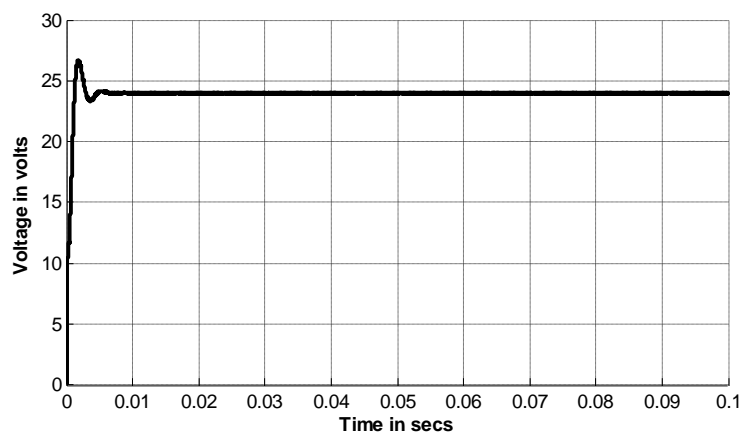

Fig.5. Simulated start-up of the output voltage with set point $24 \mathrm{~V}$ and nominal load $100 \Omega$

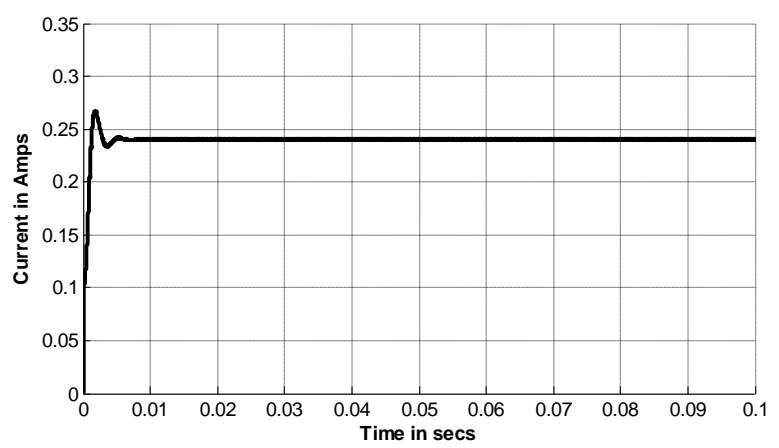

Fig.6. Simulated start-up of the output current with set point $24 \mathrm{~V}$ and nominal load $100 \Omega$

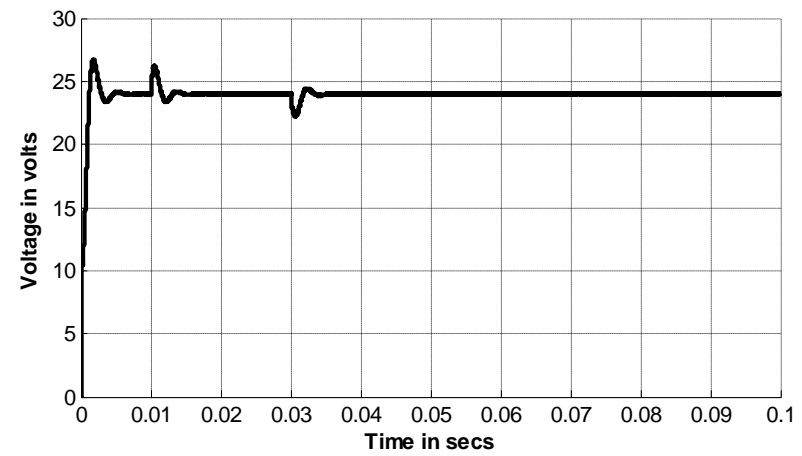

Fig.7. Simulated output voltage with line disturbances $(12 \mathrm{~V}-15 \mathrm{~V}-12 \mathrm{~V})$ under nominal load $100 \Omega$

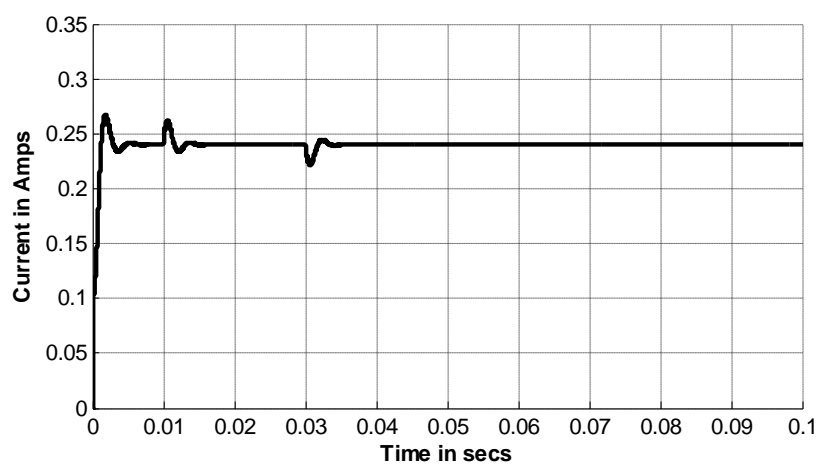

Fig.8.Simulated output current with line disturbances (12V-15V-12V) under nominal load $100 \Omega$ 


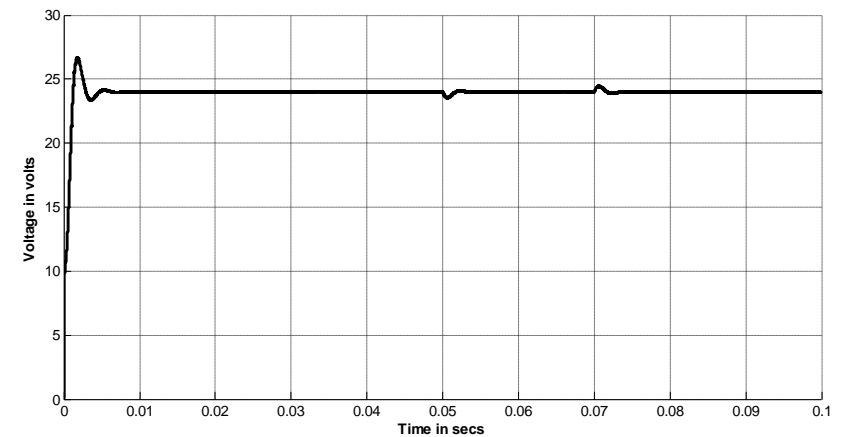

Fig.9. Simulated output voltage with load disturbances $(100 \Omega-90 \Omega-100 \Omega)$

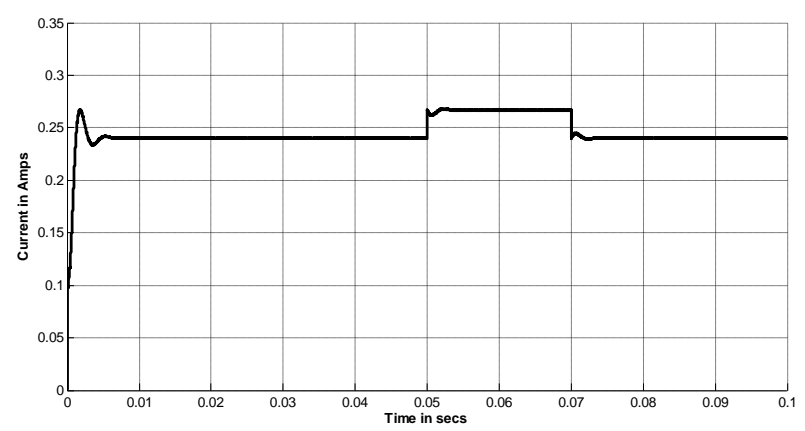

Fig.10. Simulated output current with load disturbances $(100 \Omega-90 \Omega-100 \Omega)$

\subsection{Neuro controller}

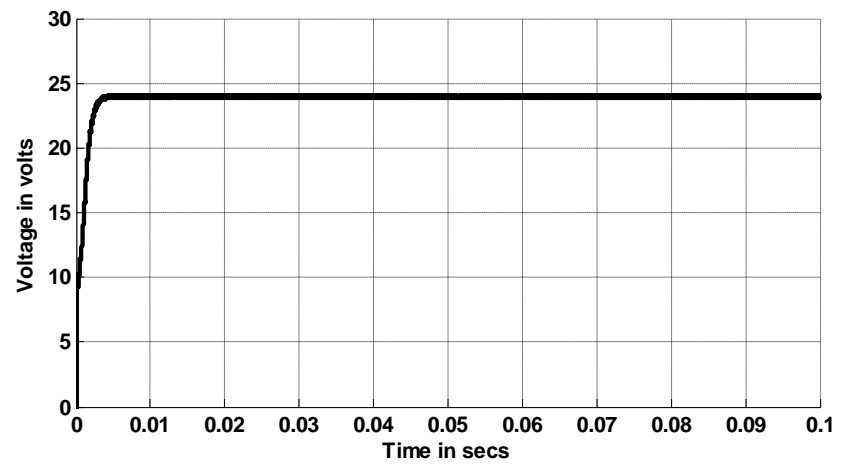

Fig.11.Simulated start-up of the output voltage with set point $24 \mathrm{~V}$ and nominal load $100 \Omega$

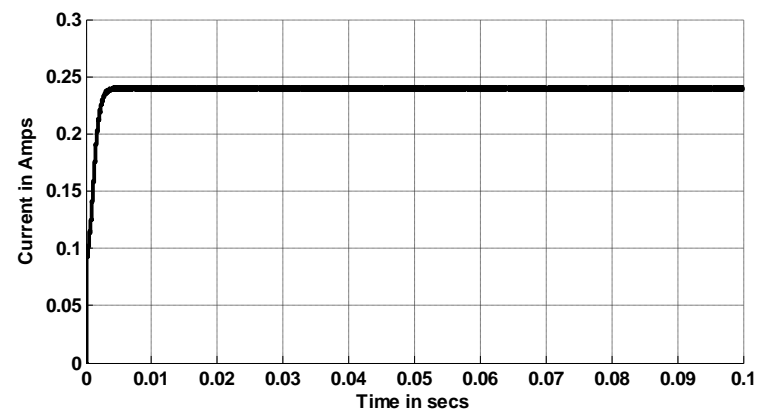

Fig.12.Simulated start-up of the output current with set point $24 \mathrm{~V}$ and nominal load $100 \Omega$ 


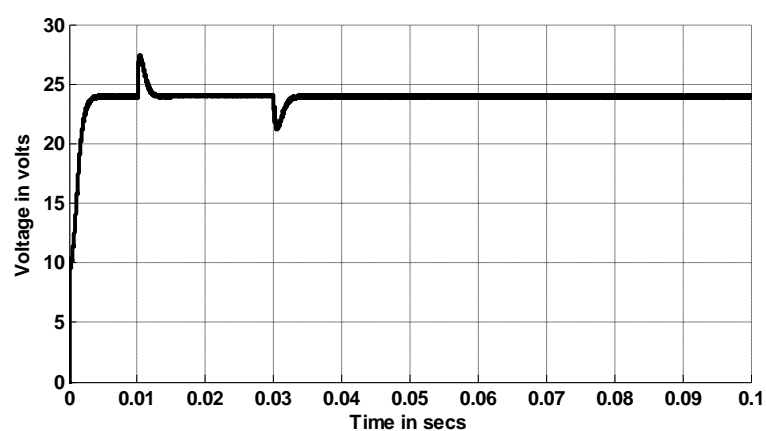

Fig.13.Simulated output voltage with line disturbances (12V-15V-12V) under nominal load $100 \Omega$

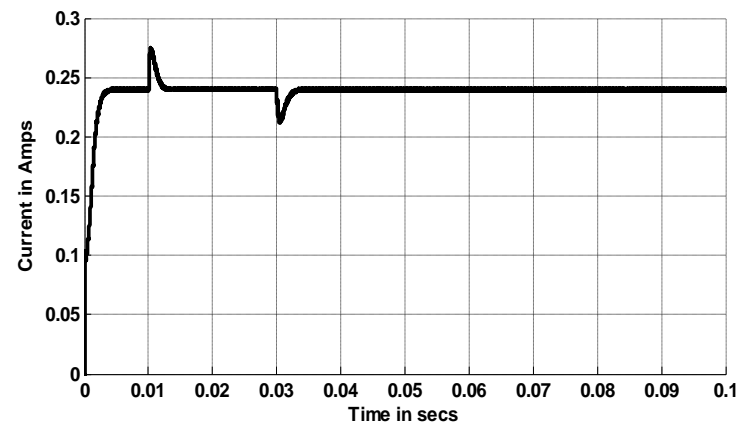

Fig.14. Simulated output current with line disturbances (12V-15V-12V) under nominal load $100 \Omega$

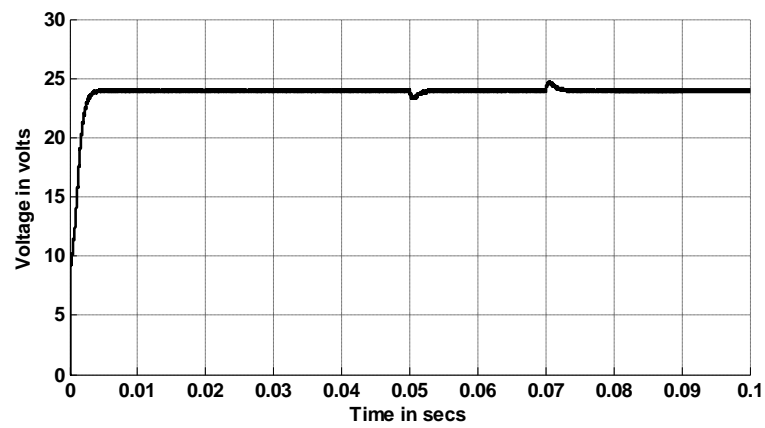

Fig.15. Simulated output voltage with load disturbances $(100 \Omega-90 \Omega-100 \Omega)$

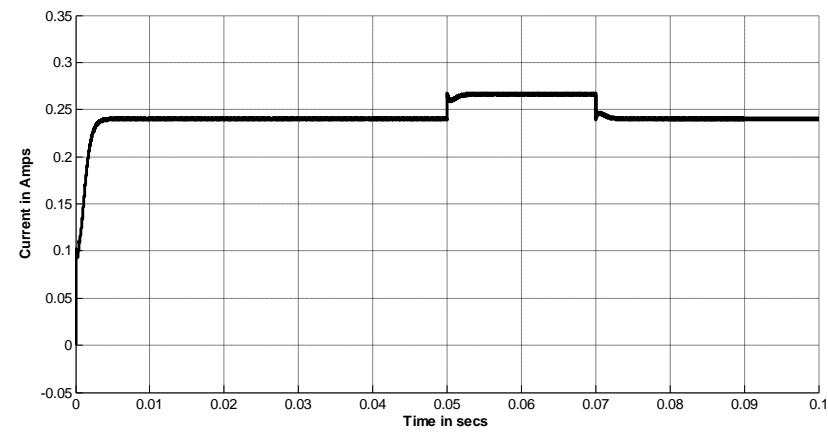

Fig.16. Simulated output current with load disturbances $(100 \Omega-90 \Omega-100 \Omega)$ 
Table 2: Performance evaluation of PI controller for super-lift re-lift Luo converter with resistive load using MATLAB

\begin{tabular}{|c|c|c|c|c|c|c|c|c|c|c|c|c|}
\hline \multirow[b]{3}{*}{$\begin{array}{l}\text { Delay } \\
\text { time } \\
(\mathrm{ms})\end{array}$} & \multirow[b]{3}{*}{$\begin{array}{l}\text { Rise } \\
\text { time } \\
(\mathrm{ms})\end{array}$} & \multicolumn{3}{|c|}{ Startup Transient } & \multicolumn{4}{|c|}{ Line Disturbance } & \multicolumn{4}{|c|}{ Load disturbance } \\
\hline & & & & & $\begin{array}{l}\text { Suppl } \\
25 \%\end{array}$ & ncrease & $\begin{array}{l}\text { Suppl } \\
25 \%\end{array}$ & decrease & $\begin{array}{l}\text { Load } \\
10 \%\end{array}$ & crease & $\begin{array}{l}\text { Load } \\
10 \%\end{array}$ & crease \\
\hline & & $\begin{array}{l}\text { Peak } \\
\text { over } \\
\text { shoot } \\
(\%)\end{array}$ & $\begin{array}{l}\text { Peak } \\
\text { time } \\
(\mathrm{ms})\end{array}$ & $\begin{array}{l}\text { Settl } \\
\text { ing } \\
\text { time } \\
(\mathrm{ms})\end{array}$ & $\begin{array}{l}\text { Peak } \\
\text { over } \\
\text { shoot } \\
(\%)\end{array}$ & $\begin{array}{l}\text { Settling } \\
\text { time } \\
(\mathrm{ms})\end{array}$ & $\begin{array}{l}\text { Peak } \\
\text { over } \\
\text { shoot } \\
(\%)\end{array}$ & $\begin{array}{l}\text { Settling } \\
\text { time } \\
(\mathrm{ms})\end{array}$ & $\begin{array}{l}\text { Peak } \\
\text { over } \\
\text { shoot } \\
(\%)\end{array}$ & $\begin{array}{l}\text { Settling } \\
\text { time } \\
(\mathrm{ms})\end{array}$ & $\begin{array}{l}\text { Peak } \\
\text { over } \\
\text { shoot } \\
(\%)\end{array}$ & $\begin{array}{l}\text { Settling } \\
\text { time } \\
(\mathrm{ms})\end{array}$ \\
\hline 0.39 & 1 & 11.3 & 1.77 & 6 & 9.2 & 4.6 & 7.7 & 4.5 & 1.95 & 3.4 & 1.91 & 3.4 \\
\hline
\end{tabular}

Table 3 : Performance evaluation of neuro controller for super-lift re-lift Luo converter with resistive load using MATLAB

\begin{tabular}{|c|c|c|c|c|c|c|c|c|c|c|c|c|}
\hline \multirow[b]{3}{*}{$\begin{array}{l}\text { Delay } \\
\text { time } \\
(\mathrm{ms})\end{array}$} & \multirow[b]{3}{*}{$\begin{array}{l}\text { Rise } \\
\text { time } \\
(\mathrm{ms})\end{array}$} & \multicolumn{3}{|c|}{ Startup Transient } & \multicolumn{4}{|c|}{ Line Disturbance } & \multicolumn{4}{|c|}{ Load disturbance } \\
\hline & & & & & $\begin{array}{l}\text { Suppl } \\
25 \%\end{array}$ & ncrease & $\begin{array}{l}\text { Suppl } \\
25 \%\end{array}$ & decrease & $\begin{array}{l}\text { Load } \\
10 \%\end{array}$ & crease & $\begin{array}{l}\text { Load } \\
10 \%\end{array}$ & crease \\
\hline & & $\begin{array}{l}\text { Peak } \\
\text { over } \\
\text { shoot } \\
(\%)\end{array}$ & $\begin{array}{l}\text { Peak } \\
\text { time } \\
(\mathrm{ms})\end{array}$ & $\begin{array}{l}\text { Settl } \\
\text { ing } \\
\text { time } \\
(\mathrm{ms})\end{array}$ & $\begin{array}{l}\text { Peak } \\
\text { over } \\
\text { shoot } \\
(\%)\end{array}$ & $\begin{array}{l}\text { Settling } \\
\text { time } \\
(\mathrm{ms})\end{array}$ & $\begin{array}{l}\text { Peak } \\
\text { over } \\
\text { shoot } \\
(\%)\end{array}$ & $\begin{array}{l}\text { Settling } \\
\text { time } \\
(\mathrm{ms})\end{array}$ & $\begin{array}{l}\text { Peak } \\
\text { over } \\
\text { shoot } \\
(\%)\end{array}$ & $\begin{array}{l}\text { Settling } \\
\text { time } \\
(\mathrm{ms})\end{array}$ & $\begin{array}{l}\text { Peak } \\
\text { over } \\
\text { shoot } \\
(\%)\end{array}$ & $\begin{array}{l}\text { Settling } \\
\text { time } \\
(\mathrm{ms})\end{array}$ \\
\hline
\end{tabular}

\section{Conclusion}

The simulation results show that the proposed conventional controller and neuro controller regulate satisfactorily the output voltage of positive output super-lift re-lift Luo converter irrespective of line and load disturbances. Performance evaluations of simulated controllers are carried out as reported in Table 2 and 3 from which it is found that neuro controller performs effectively for the chosen converter when settling time is the performance measure whereas PI controller creates less over shoot.

\section{REFERENCES}

[1] F.L.Luo and H.Ye, Positive output super-lift converters voltage lift technique, IEEE Trans.Power Electron., 18, 2003,105-113

[2] F.L.Luo, Positive output Luo-converters, voltage lift technique, Proc.Inst.Elect.Eng., 146(4), 1999, 415-432.

[3] Power Electronics Hand Book, M.H.Rashid.Ed., Academic, San Diego, CA, Aug.2001.

[4] F.L.Luo, Re-Lift Circuit: a new DC-DC step-up (boost) converter, IEE Electronics Letters, 33(1), 1997, 5-7.

[5] F.L.Luo, Re-Lift converter: design, test, simulation and stability analysis, IEE Proceedings on EPA, 45(4), 1998, 315-325.

[6] F.L.Luo, Luo converters, new DC-DC step-up converters, Proceedings of the International Conference ISIC-97, 1997, Singapore, 227230 .

[7] F.L.Luo, Luo converters, a series of new DC-DC step-up (boost) conversion circuits, Proceedings of IEEE International Conference PEDS'97, 1997, Singapore, 582-589.

[8] A.Joseph Basanth, S.P.Natarajan and T.S.Siva kumaran, Development of FLC for ZCS LUO QRC, International Conference PESA09, Hong Kong.

[9] A.Joseph Basanth, S.P.Natarajan and T.S.Siva kumaran, Simulation and DSP based implementation of double output elementary luo converter, International Conference PESA-09, Hong Kong. 